In such ways, the new privates expand access for a population otherwise marginalized. However, the quality of the teaching methods, learning content and programs, remain questionable.

Two years ago, all old privates and publics but only some of new privates carried out a voluntary institutional self-evaluation process, focusing on strengths and weaknesses followed by an external peer review and the drafting of a plan of action. As a result, the majority of the participating institutions are interested in setting up an independent national accreditation system. Several new private universities have already sought accreditation through private regional accreditation agencies. However, most of them are concerned about their ability to meet international accreditation standards and the consequences that may result from failure. While Nicaragua's higher education institutions, especially the new private institutions, are still far from reaching international standards, recent advances hold promise for bringing the country closer to the Latin American region overall.

Nicaragua's new private universities reflect some trends elsewhere in Central America, Latin America more broadly, and even globally. These developments include rapid growth, accommodation where demand exceeds public supply, small institutional size, interinstitutional variation, questionable quality, private finance, and profiles and prospects much in flux.

\section{New Private Universities in}

\section{Nigeria}

\section{ISAAC N. OBASI}

Isaac N. Obasi is a senior lecturer and coordinator of the MPA Program, Department of Political Q Administrative Studies, University of Botswana. Address: Private Bag 0022, Gaborone, Botswana; and a regular columnist on higher education for the Daily Champion newspaper, Lagos, Nigeria. Email: zikobasi@yahoo.com and obasiin@mopipi.bw.

$\mathrm{P}$ ivate universities in Nigeria have evolved during two historical phases. The first phase, during the period of Nigeria's second democratic experiment (1979-1983), private universities emerged without any planning for their development and were later abolished by a military regime in 1984 . Both prior to and during this period, official thinking followed mainly two Presidential Commissions on Higher Education in Nigeria-the Ashby Commission (I962) and the Cookey Commission (I98I) - that were very conservative about the proliferation of universities (public or private).

The second phase in the evolution of private universities (under the present Obasanjo government, I999-) occurred as part of a planned development. Since I999, 24 private universities have been licensed in response to over Ioo applications received by the National Universities Commission, a federal government agency charged with the regulation, accreditation, and monitoring of universities (both public and private).

\section{The New Private Surge}

The first explanation for the new private surge lies with the "public failure theory" expounded in classic literature (e.g., cases of Mexico and Peru) - the problems of public universities, leading to yielding important ground to the emergence of private universities. A second explanation also lies in the literature, but this is "demand absorption," as public supply of higher education falls short of new demand. For example, in I995, the admissions rate of public universities was a scant 6 percent of applications received, and between 1995 and 1998 the average was 16 percent. The private demand-absorbing role is similar to what has happened in some other African countries and elsewhere outside the region.

The third major explanation adapted from elsewhere for the

\section{The first explanation for the new private surge lies} with the "public failure theory"

surge concerns differentiated functions offered by private universities. Taken together, the three reasons fit into broader international higher education reform trends.

\section{EMERGing Features}

In relation to developments in the aborted first phase (1979-I983), the new private universities are a significant improvement. For example, their establishment was meant to conform to some expectations of accreditation standards in areas of staffing, finance, establishment of infrastructure, and provision of facilities and services. Some even have modern facilities not found in their public counterparts. And secondly, in comparison with their public counterparts, the new privates have more cost-effective, lean governance structures rather than the overbureaucratized type of structures. Some are modeled on American-type governance structures as reflected, for example, in the adoption of such nomenclatures as president and vice-president in place of vice-chancellor and deputy vicechancellor. This is also reflected in the adoption of the cost-saving collegiate system in place of the conventional structures of faculties and departments.

The key emerging features of Nigeria's new private universities involve ownership, enrollments, and tuition level. The ownership of private universities in Nigeria is dominated by religious organizations. Of the 24 licensed institutions, I5 are owned by three major religious organizations. The Orthodox/Pentecostal Church organizations have 9 (37.5 per- 
cent), Catholic Church organizations own 3 (I2.5 percent), while the Islamic organizations also own 3 . The rising profile of indigenous Pentecostal churches that own private universities is especially noteworthy. These churches have large membership and enormous wealth; they are concentrated in the southwest region of the country, which is where the majority of the private universities are located.

Enrollments show significant potential for growth—at least based on evidence from one of oldest new private universities. Madonna University, which graduated 390 students during its first convocation ceremony in 2004 , had 7,000 students as of

The ownership of private universities in Nigeria is dominated by religious organizations.

2005 .

Tuition fees range from US\$769 to US\$3,285 annually. Some universities include meals and textbooks with their fees while others do not. The fees charged differ across universities and also across disciplines in the same universities. As in Kenya and Uganda, both high and low fee structures exist side by side. Also as in Kenya, Nigeria has some American-type high-cost private universities. Three notable ones are the PanAfrican University in Lagos, ABTI-American University in Yola, and Igbinedion University in Okada. This price differentiation represents a normal feature of a market-driven higher education system, especially with diverse ownership structures.

\section{Any Value Added Thus Far?}

Currently setting the pace in some of their services and functions, private universities have become a challenge to their public counterparts. So far, they have continued to maintain stable academic calendars unlike the often-disrupted public universities. The new private universities have nipped in the bud the secret-cult organizations present among students in public universities; the clashes, violence, and killings involving these groups have become a regular feature for well over a decade now. The teaching and learning environment has generally been better in the private than in the public universities. With respect to standards, on average the privates have done much better in the National Universities Commission's accreditation process than their public counterparts. For example, in the commission's 2005 accreditation, none of the programs evaluated in five private universities failed accreditation as did many of their public counterparts. The 2006 accreditation again confirmed the higher rating of private universities. Here may well lie the greatest contributions made by the privates so far, as the emerging institutional competition would eventually help to restore the lost glory of higher education in Nigeriaafter the devastation wrought partly by the long period of military dictatorship. A private quality edge would also counter the more prevalent African situation in which the top universities continue to be located in the public sector.

\section{Chinese Higher Education in an Open-Door Era}

\section{Philip G. Altbach}

Philip G. Altbach is Monan professor of higher education and director of the Center for International Higher Education at Boston College.

Cipiri hina is opening its doors to foreign higher education providers at a time when competition and markets are being expanded domestically. Today, about I,400 foreign higher education institutions have been approved by various education authorities in China to operate in the country. This large number brings both promise and peril. The opportunity to bring new academic ideas and practices into the country may also be interpreted as a powerful invitation for problems and crises.

As Chinese higher education is being increasingly deregulated internally, the Ministry of Education is permitting foreign providers to operate. Many Chinese universities face financial shortfalls and thus explore new ways of generating revenues. Among these new market ideas are linkages with foreign providers - the thought being that an overseas connection will bring prestige, a sense of cosmopolitanism, and perhaps some new educational concepts. The central government, provincial and municipal authorities, and university administrators have all embraced internationalization for many reasons - the most important of which are commercial benefits and the need to provide access to those seeking a postsecondary degree.

\section{Foreign Motivations and Programs}

China's expanded freedom of access coincides with a growing interest in China among other countries. Again, the main foreign motivation is commercial, but there are mixed rationales from abroad. Universities worldwide see China as a major market-for recruiting students to study abroad, for "buying" some of the brightest Chinese scientists for academe and industry, and now for exporting educational programs and institutions. Chinese policymakers and institutions should remember that while foreign partners' own purposes and motives may often coincide with Chinese interests, it is possible that sometimes they might not.

Foreign institutions and governments have other motivations as well. A few foreign universities have strong historical links to China, and their motives are mainly academic. For example, the Hopkins-Nanjing master's program has been operating for more than two decades, and the ties between the 